\title{
Fertiliser sulphur for North Canterbury pastures
}

\section{AgResearch, Invermay Agricultural Centre, PB 50034, Mosgiel}

\begin{abstract}
Natural inputs of sulphur in North Canterbury are restricted to $1-2 \mathrm{~kg}$ of sulphur(S)/ha/year in rainfall. On the limited area of irrigated land a further $7 \mathrm{~kg}$ of $\mathrm{S}$ may be added in irrigation water. These inputs are inadequate to replace losses which occur through leaching, removal in animal products, and excretal transfer, so fertiliser $\mathrm{S}$ is essential to maintain farming systems. The choice of form of fertiliser varies from sulphate, to mixtures of sulphate and elemental $\mathrm{S}$, to elemental $\mathrm{S}$ forms. Focus in this paper is on the forms which will be effective in North Canterbury, other factors which influence choice of fertilisers, and recommended fertilisers for different farming situations.
\end{abstract}

K eywords: elemental sulphur, fertiliser recommendations, rate constant, sulphur oxidation, sulphur superphosphate

\section{Introduction}

-Sulphur-(S)-is-one of-the-major nutrient-deficiencies-in New Zealand soils (Walker \& Gregg 1975). Fertiliser inputs of $S$ are needed in grazed pastures because losses of sulphate from the soil are in excess of the low levels of natural inputs of $S$ to the system.

There are two chemical forms of $\mathbf{S}$ fertiliser available in New Zealand: sulphate and elemental sulphur $\left(\mathbf{S}^{0}\right)$. The sulphate form is readily available to plants while $\mathbf{S}^{0}$ is a slow-release form. The choice of forms for' North Canterbury pastures depends on the stage of development of the pasture, rainfall, irrigation, types of soil, and intensity of-farming.

The purpose of this paper is to use research information relevant to the region in order to identify the most suitable $\mathbf{S}$ fertilisers for North Canterbury pastures.

\section{Inputs of $\mathrm{S}$}

Natural additions of $\mathbf{S}$ accrue from the weathering of the soil parent material, from the atmosphere, and in irrigation water. The additions from weathering are minimal; most of the sulphate released is immediately lost by leaching (Syers et al. 1970; Walker \& Gregg 1975). In inland North Canterbury typical atmospheric inputs are 1-2 kg S/ha/year (Walker \& Gregg 1975). Although Close \& Woods (1986) reported a rainfall input of $8.9 \mathrm{~kg} \mathrm{~S} / \mathrm{ha}$ on the Amuri Plains in 1980-81, it probably included dust contaminants from the developing irrigation scheme.

North Canterbury irrigation water contains low levels of dissolved sulphate (e.g. the median concentration from 12 monthly samplings at Mandamus (Hurunui River) in 1989 was 1.2 ppm sulphate-S, DG Smith NIWA Ecosystems pers.comm.). A high rate of application of $600 \mathrm{~mm}$ of irrigation water per year would give an addition of $7.2 \mathrm{~kg}$ of $\mathrm{S} / \mathrm{ha} / \mathrm{year}$.

\section{Losses of $\mathrm{S}$}

Most losses of $\mathbf{S}$ from the soil are by take off in animal and plant produce, excretal transfer by grazing animals, runoff and especially leaching.

Over a 38 year period losses of $\mathbf{S}$ from grazed irrigated pastures at Winchmore which had received either 188 or $376 \mathrm{~kg}$ superphosphate/ha/year ( 21 or 42 $\mathrm{kg} \mathrm{S} / \mathrm{ha} / \mathrm{year}$ ) amounted to $48 \%$ and $73 \%$ of the fertiliser S applied (Williams \& Haynes 1992). After 35 years -net-annual-losses-of ${ }^{-} S^{-}$from-the-same- pastures $^{-}$(24-and $43 \mathrm{~kg} \mathrm{~S} / \mathrm{ha}$ respectively) were slightly in excess of the total annual fertiliser S inputs (Nguyen \& Goh 1992). The losses were mainly by leaching, included in which was $70 \%$ of the urine S (Nguyen \& Goh 1992). On North Island hill soils which, like the hill soils in North Canterbury, had low S-retention properties, between $46 \%$ and $77 \%$ of the fertiliser $\mathbf{S}$ (superphosphate) applied over 12 years was estimated to be lost by leaching (Saggar et al.1990). As on irrigated land, these losses include a component of loss through animal transfer and concentration of $\mathbf{S}$ at urine spots, before eventual loss by leaching.

In the North Canterbury region greatest leaching losses occur on the irrigated plains. The North Canterbury irrigation schemes were designed to supply $100 \mathrm{~mm}$ of water over the irrigated area at return times of about 16 days. The amount of water held by the irrigated soils (available water holding capacity) varies from $40 \mathrm{~mm}$ to over $100 \mathrm{~mm}$. Therefore up to $60 \%$ of the water applied along with its dissolved $\mathrm{S}$, and any soil sulphate it picks up (especially from high concentrations of $\mathrm{S}-$ e.g. after fertiliser application at say $25-30 \mathrm{~kg} \mathrm{~S} / \mathrm{ha}$, or at urine spots where Nguyen \& Goh (1993) estimated $\mathbf{S}$ was deposited at SO-100 kg/ 
ha) can be lost from the system almost immediately by leaching beyond the rooting zone of the pasture plants. The mean measured drainage from five representative sites on the Waiau scheme over a 2 year period was $600 \mathrm{~mm}$ or $50 \%$ of the $1200 \mathrm{~mm}$ applied as irrigation (Close \& Woods 1986).

Typical $\mathrm{S}$ losses in animal product (e.g. $4.5 \mathrm{~kg}$ wool x $3.4 \% \mathrm{~S}+30 \mathrm{~kg}$ lamb $\times 0.15 \% \mathrm{~S}+60 / 5 \mathrm{~kg}$ ewe $\mathrm{x}$ $0.15 \% \mathrm{~S}$ ) can be calculated as $0.22 \mathrm{~kg} \mathrm{~S}$ per stock unit per year. This assumes 20\% replacement of animals per year. For intensive dairy production similar losses per stock unit can be expected e.g. $1.8 \mathrm{~kg}$ S/cow or $0.24 \mathrm{~kg} \mathrm{~S}$ per stock unit per year (7.5 su /cow).

\section{Forms of $\mathrm{S}$ fertiliser}

Sulphur fertilisers available in New Zealand are either in sulphate or elemental sulphur $\left(\mathbf{S}^{\mathbf{0}}\right)$ forms. Plants can take up S only as sulphate; thus the $\mathrm{S}$ in sulphate fertilisers is immediately available to plants on the dissolution of the fertiliser. In contrast $S^{0}$ has'to be oxidised to sulphate before it can be taken up by plants. Single superphosphate, ammonium sulphate (sulphate of ammonia), potassium sulphate and gypsum are examples of sulphate fertilisers; S-bentonite fertilisers (e.g. Tiger-90), and screened agricultural $S$ (no longer available commercially) are examples of elemental $\mathrm{S}$ fertilisers. The best-known $\mathrm{S}^{0}$-containing fertilisers also contain sulphate-S; they are mixtures of $S^{0}$ and superphosphate known as $S$ superphosphates containing $20,28,33,40$ or $50 \% \mathrm{~S}$ (Table 1). All are manufactured by spraying molten elemental $S$ onto the acidulating phosphate rock during the manufacture of the superphosphate. The $\mathbf{S}^{\mathbf{0}}$ component is fully integrated into the matrix of the superphosphate, is relatively finely divided, and the products are safe.

The rate of oxidation of $\boldsymbol{S}^{0}$ depends on the surface area of the $S$ particles available to be colonised by oxidising micro-organisms in the soil. For rapid oxidation very tine $\mathbf{S}^{\mathbf{0}}$ particles are required. However, very fine dry particles of $\mathbf{S}^{0}$ are difficult to handle and apply as a fertiliser, and most importantly are a fire and explosive hazard. Fine dry $\mathbf{S}^{\mathbf{0}}$ is thus impractical as a commercial fertiliser. Dry $\mathrm{S}^{0}$ as screened agricultural $\mathrm{S}$, in which the distribution of fine particle sizes was controlled by aviation safety standards, was however available until 1992. 50\%S superphosphate has superceded screened agricultural $S$ in supplementing the $\mathrm{S}$ content of fertiliser mixtures (e.g. with diammonium phosphate $(=\mathrm{DAP} ; 18 \% \mathrm{~N}, 20 \% \mathrm{P})$; reactive phosphate rock (=RPR; $13 \% \mathrm{P})$ a slow release $\mathrm{P}$ fertiliser; partially acidulated rock phosphate (=PAR; $10 \% \mathrm{P}, 8 \% \mathrm{~S}$ ); and 'long life' super, a product containing readily available and slowly available $P$.
Table $1 \mathbf{S}^{\mathbf{0}}$ particle size distribution in molten-mixed $\mathrm{S}$ superphosphates manufactured in New Zealand and analysed at Invermay (cumulative \% of $S$ in different size ranges).

\begin{tabular}{|c|c|c|c|c|c|}
\hline & \multirow[b]{2}{*}{$\begin{array}{c}\text { Screened } \\
\text { Agricultural } \\
\text { S }\end{array}$} & \multicolumn{4}{|c|}{$\begin{array}{l}\text { - } S^{0} \text { fertiliser } \\
\text { molten-mixed } \\
\text { S-superphosphate products }\end{array}$} \\
\hline & & $\begin{array}{c}20 \% \\
\text { S-super }\end{array}$ & $\begin{array}{c}20 \% \\
\text { S-super }\end{array}$ & $\begin{array}{c}33 \% \\
\text { S-super }\end{array}$ & $\begin{array}{c}50 \% \\
\text { S-super }\end{array}$ \\
\hline \multirow{3}{*}{$\begin{array}{l}\text { Total-S \% } \\
\mathrm{SO}_{4}-\mathrm{S} \% \\
\mathrm{~S}^{0} \% \\
\text { Size ranges }\end{array}$} & 100 & 20 & 26 & 33 & 50 \\
\hline & & 10 & 9 & 8 & 6 \\
\hline & 100 & 10 & 19 & 25 & 44 \\
\hline$<2.0 \mathrm{~mm}$ & 99 & 97 & 100 & 100 & 99 \\
\hline $\begin{array}{l}<1.0 \mathrm{~mm} \\
<500 \mu \mathrm{m}\end{array}$ & $\begin{array}{l}67 \\
42\end{array}$ & $\begin{array}{l}96 \\
93\end{array}$ & $\begin{array}{c}100 \\
98\end{array}$ & $\begin{array}{c}100 \\
97\end{array}$ & $\begin{array}{l}98 \\
90\end{array}$ \\
\hline$<250 \mu \mathrm{m}$ & 26 & 90 & 09 & 75 & 54 \\
\hline$<150 \mu \mathrm{m}$ & 17 & 77 & 65 & 59 & 22 \\
\hline$<75 \mu \mathrm{m}$ & 9 & 36 & 29 & 37 & 7 \\
\hline$<38$ pm & 3 & 15 & 12 & 17 & $!$ \\
\hline
\end{tabular}

Other $\mathrm{S}$ fertilisers available in New Zealand include imported Tiger 90 (a mixture of $90 \% \quad \mathbf{S}^{0}$ and bentonite clay in a prilled form, which when wetted disperses and releases the $\mathbf{S}^{\mathbf{0}}$ ), natural deposits of $\mathbf{S}$ in pumice in the central North Island, solid $\mathbf{S}^{\mathbf{0}}$ particles to specified size ranges made from a molten $\mathrm{S}$ by-product of petroleum production, and 'filter-cake $S$ ' a $60 \% \quad \mathbf{S}^{0}$ byproduct of superphosphate manufacture.

\section{Availability of $S$ from elemental $S$ fertilisers}

The availability of sulphate from $\mathbf{S}^{0}$ fertilisers depends on the rate of $\mathbf{S}^{\mathbf{0}}$ oxidation which depends primarily on particle size of the $\mathbf{S}^{\mathbf{0}}$ and soil temperature. The particle size distributions of $\mathbf{S}^{\mathbf{0}}$ in different $\mathbf{S}$ superphosphates measured at Invermay over a number of years are shown in Table 1. Screened agricultural $S$ is included for historical reference. Among the $\mathrm{S}$ superphosphate mixtures, the general rule is that as the $\mathbf{S}^{0}$ content increases the size of the $\mathbf{S}^{0}$ particles increases (Table 1). Particle size distributions of $\mathbf{S}^{\mathbf{0}}$ from other fertiliser products available in New Zealand have been reported by Boswell \& Swanney (1986) and Boswell \& Friesen (1993).

Mean rates of $\mathbf{S}^{\mathbf{0}}$ oxidation vary with different regional soil temperatures $(0-10 \mathrm{~cm})$. Using the North Canterbury region mean rate constant $(\mathrm{a}=0.15$; Watkinson \& Lee 1994), the amount of $S^{0}$ of known particle size which is oxidised in a given time can be calculated, and the suitability of different $S^{0}$ fertilisers to soils in the region can be evaluated. This procedure was followed to show the times calculated for the oxidation of the $\mathrm{S}^{0}$ in Tiger $90,50 \% \mathrm{~S}$ superphosphate, 
$20 \% \mathrm{~S}$ superphosphate, and fine sulphur particles (75$150 \mathrm{~mm}$ ) (Figure 1). In fact the rate of oxidation varies within a region. Boswell et al.(1992) predicted large differences in rates between north and south aspects of North Canterbury hills, being more rapid on warmer north facing slopes. Other $\boldsymbol{S}^{0}$ oxidation experiments conducted on North Canterbury foothill soils (Hurunui and Gorge soils, Sinclair et al.1985) confirmed the requirement for particles to be $<150 \mathrm{~mm}$ for complete oxidation to occur within a year of application.

Figure 1 Comparison of oxidation rates of the elemental $\mathrm{S}$ in different $S$ fertilisers.

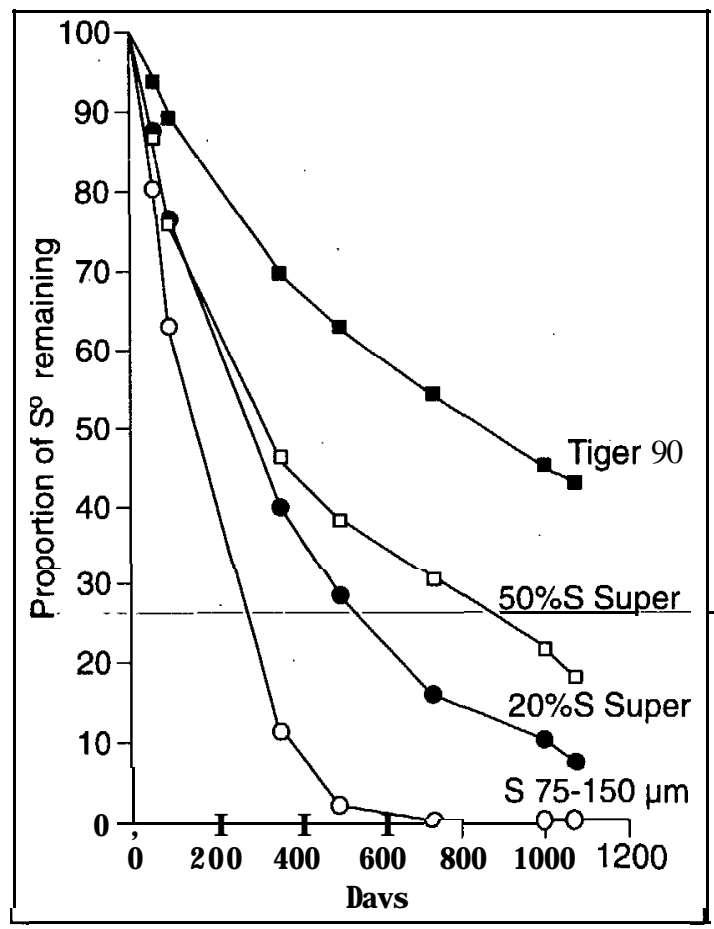

The oxidation rates for $\mathrm{S}^{0}$ in_28\% S, 33\%S, and $40 \% \mathrm{~S}$ superphosphates are intermediate between those shown for the $20 \%$ S and $50 \% \mathrm{~S}$ superphosphates in Figure 1. The time required to oxidise $80 \%$ of the $\mathbf{S}^{0}$ applied in $20 \% \mathrm{~S}$ super in North Canterbury is about 2 years while for $50 \% \mathrm{~S}$ super it takes about 3 years. Tiger 90 disperses into particles that are too coarse for practical application in North Canterbury. However, when Tiger 90 is used as the $\mathrm{S}$ source in aerial application of slurries it is dispersed in water and ground. The resulting $\mathbf{S}^{\mathbf{0}}$ particles are likely to be closer to the particles $75-150 \mathrm{~mm}$ than those from the dispersed prills shown in Figure 1 and the $S$ component of the slurry will be correspondingly more effective.
The minor disadvantage in the use of $\mathbf{S}^{0}$ as a fertiliser is its acidifying effect on soil. One $\mathrm{kg}$ of $\boldsymbol{S}^{0}$ has an acidifying effect which requires three $\mathrm{kgs}$ of lime to neutralise (During 1984). The effect on soil $\mathbf{p H}$ is likely to be greatest in poorly buffered soils (e.g. dryland;often coarse-textured soils with low organic matter contents), at high rates of $S$ (>100 kg S/ha) and where oxidation of $\mathbf{S}^{\mathbf{0}}$ is rapid.

\section{Factors affecting choice of $\mathrm{S}$ fertiliser}

The choice of $S$ fertilisers for any given pasture situation is governed first by the effectiveness of the fertilisers and secondly costs. The effectiveness of the fertiliser depends on the immediacy of requirement of sulphate, the requirement for other nutrients, and the need to restrict leaching losses. The important cost considerations are the relative costs of the $S$ and other nutrients, and the concentration of nutrients which affect the cost of transport and application.

\section{Availability of sulphate:}

Immediate availability of sulphate is required at pasture establishment because the seedling plants require the nutrient in a chemically and physically accessible form for the small root systems. Sulphate fertilisers (e.g. superphosphate) should therefore be used. For maintenance of established pasture $\mathbf{S}^{\mathbf{0}}$ fertilisers supply sulphate at a rate better suited to the requirements of the perennial pasture plants.

\section{Other nutrients:}

Most North Canterbury pastures require $\mathrm{S}$ and $\mathrm{P}$. S requirements are greater in dry soils. Increasing requirements for $\mathrm{P}$ relative to $\mathrm{S}$ follow the pattern of increasing rainfall and consequently greater soil development, weathering and leaching. The relationship of $\mathrm{S}$ and $\mathrm{P}$ requirements to soil groups is discussed later.

Under low rainfall $(<800 \mathrm{~mm}), \mathrm{S}$ is likely to be the only deficiency in rendzina soils_formed on limestone. Rendzinas usually have high natural fertility especially $\mathrm{P}$ and K. Sulphur deficiencies result from rapid leaching of sulphate from the often shallow $(15-30 \mathrm{~cm})$ topsoils into the parent rock directly beneath. Table 2 summarises the large responses to $27 \mathrm{kgS} / \mathrm{ha}$ applied to a rendzina soil at Waihao Downs in South Canterbury (0-75 mm depth, Olsen- $\mathrm{P}=40$, sulphate- $S=4 \mathrm{ppm}$ ); with a 20-year history of an average $100 \mathrm{~kg}$ superphosphate/ ha/year. The responses were to $S$ alone. Overall responses to three different forms of $S$ fertiliser were similar, however, gypsum and $28 \% \mathrm{~S}$ superphosphate had greater effects in the first year while the delayed response to the S-bentonite reflected the time required 
Table 2 Seasonal pasture dry matter accumulation in response to a single application ( $27 \mathrm{~kg} \mathrm{S/ha)}$ of different $\mathrm{S}$ fertilisers on a rendzina soil at Waihao Downs, South Canterbury (kg DM/ha).

\begin{tabular}{|c|c|c|c|c|c|c|c|c|}
\hline \multirow{2}{*}{$\begin{array}{l}\text { Fertiliser } \\
\text { Treatment }\end{array}$} & \multicolumn{4}{|c|}{ 1985/86 } & \multicolumn{4}{|c|}{ 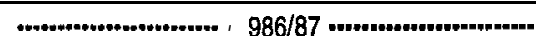 } \\
\hline & Sprina & Summer & Autumn & Year & Spring & Summer & Autumn & Total \\
\hline $\begin{array}{l}\text { 28\% S-super } \\
\text { S-bentonite } \\
\text { Gypsum } \\
\text { Control (Nil S) }\end{array}$ & $\begin{array}{l}1620 a^{\prime} \\
1830 \mathrm{a} \\
1870 \mathrm{a} \\
1570 \mathrm{a}\end{array}$ & $\begin{array}{l}2320 \mathrm{a} \\
1510 \mathrm{~b} \\
2280 \mathrm{a} \\
1320 \mathrm{~b}\end{array}$ & $\begin{array}{l}2300 \mathrm{a} \\
2080 \mathrm{a} \\
2250 \mathrm{a} \\
1200 \mathrm{~b}\end{array}$ & $\begin{array}{l}6350 \mathrm{a} \\
5580 \mathrm{a} \\
6540 \mathrm{a} \\
4230 \mathrm{~b}\end{array}$ & $\begin{array}{l}3930 \mathrm{ab} \\
4260 \mathrm{a} \\
3930 \mathrm{ab} \\
3460 \mathrm{~b}\end{array}$ & $\begin{array}{l}1500 \mathrm{ab} \\
1900 \mathrm{a} \\
1580 \mathrm{ab} \\
1030 \mathrm{~b}\end{array}$ & $\begin{array}{l}660 \mathrm{ab} \\
990 \mathrm{a} \\
680 \mathrm{ab} \\
460 \mathrm{~b}\end{array}$ & $\begin{array}{l}6090 \mathrm{ab} \\
7150 \mathrm{a} \\
6190 \mathrm{a} \\
4950 \mathrm{~b}\end{array}$ \\
\hline SED & 95.6 & 194.2 & 104.1 & 316.2 & 169.9 & 150.0 & 88.7 & 313.0 \\
\hline
\end{tabular}

- Within columns values with different letters differ significantly $(P<0.05)$

to oxidise the $\mathbf{S}^{0}$. The S-bentonite contained $85 \% \mathrm{~S}^{0}$, was made by the former DSIR, and on dispersion released much finer particles of $S$ than are found in Tiger 90 (Boswell et 01.1988).

Recognition of the importance of $\mathrm{P}$ and $\mathrm{N}$ requirements additional to $\mathrm{S}$ brings a need for a brief consideration of suitable $\mathrm{P}$ and $\mathrm{N}$ fertiliser forms for the region. Phosphorus is mainly supplied as the $\mathrm{P}$ component of superphosphate or $\mathrm{S}$ superphosphates. Where a high concentration $\mathrm{P}$ fertiliser is required (usually in mixtures with high concentration S superphosphate) DAP is favoured for lower, drier soils and soils with high $\mathrm{pH}$; while RPR may be practical as a maintenance fertiliser for wetter $(>800$ $\mathrm{mm}$ rainfall) soils with $\mathrm{pH}<5.5$. The acid soil conditions assist in the rate of chemical dissolution of the RPR Similarly in mixtures with $\mathbf{S}^{0}$ fertiliser the acidifying effect of oxidising $\mathbf{S}^{0}$ increases the rate of release of phosphate from the rock (Lee et al. 1987). Nitrogen is required for specific situations e.g. dairying on irrigated soils, or on dryland soils where $\mathrm{N}$ benefits production (early spring growth, given soil temperatures (at $10 \mathrm{~cm}$ depth) above $9^{\circ} \mathrm{C}$; or in autumn following a dry summer, given sufficient rain to wet the topsoil). DAP is the preferred $\mathrm{N}$ fertiliser because of its high $\mathrm{P}$ content and its availability in mixtures with $50 \% \mathrm{~S}$ superphosphate.

\section{Restricting leaching losses and application frequency:}

In soils subject to leaching, slow release $S$ fertilisers are required to restrict sulphate losses. They are best suited for maintenance fertiliser applications. Annual applications are required on irrigated soils. In the high country slow release of sulphate over a 2-3 year period can be tailored to plant production needs through the choice of fertiliser.

\section{$P$ atterns of $S$ and $P$ requirements with soil groups}

Sulphur is the major deficiency in the subhygrous yellow-grey earth soils in the $600-700 \mathrm{~mm}$ rainfall zone, including the central Amuri Plain and the low land south of it. The exception is the irrigated area of the plains where $\mathrm{P}$ requirements approach $\mathrm{S}$ requirements. Progressively more $\mathrm{P}$ is required as soils change from dry hygrous yellow-grey earths $(700-800 \mathrm{~mm})$, to yellow-grey yellow-brown earth intergrades, and the lowland yellow-brown earths $(800-1200 \mathrm{~mm})$, to upland yellow-brown earths (1200-2400 mm). Phosphorus and $S$ requirements are similar in the lowland yellow-brown earths. If fertiliser $\mathrm{P}$ requirements are greater than $\mathrm{S}$ (e.g. upland yellow brown earths) then the comparatively cheap $S$ is generally applied in excess of requirements 
e.g. in 1: $1 \mathrm{~S}: \mathrm{P}$ fertilisers such as superphosphate $(9 \% \mathrm{P}$, $11 \% S$ ), or in $S$ superphosphates. A summary of $S$ fertilisers suitable for the different soil groups and the following land forms is shown in Table 3.

\section{$S$ fertilisers for irrigated plains}

On the irrigated plains pastures are highly productive, irrigations frequent (e.g. approximately 2 week cycles, up to 6 times per season), soils are mostly shallow, plants shallow-rooted, and thus leached sulphate can be expected to quickly pass out of the pasture system. Fertiliser is required at least annually, probably more frequently on dairy pastures e.g. following silage or hay cuts, for strategic boosts in production at specific times. On pastures developed for 3.5 years under irrigation at Winchmore and under sheep grazing, superphosphate adequately met $\mathrm{S}$ requirements when applied at rates needed to correct $\mathrm{P}$ deficiency (Nguyen et al. 1983). On North Canterbury soils developed under irrigation for about 10 years, additional fertiliser $\mathrm{S}$ in $20 \% \mathrm{~S}$ or $28 \% \mathrm{~S}$ superphosphate may be required and is supplied at little extra cost. In dairy pastures there may be times of feed shortage when there is a role for $\mathrm{N}$ fertiliser in addition to a need for $\mathrm{S}$ and $\mathrm{P}$ and also potassium (K). Both $\mathrm{P}$ and $\mathrm{N}$ are supplied in high concentrations by DAP but this must be supplemented by the use of a high concentration $\mathbf{S}$ fertiliser (e.g. 50\%S superphosphate). Or, more simply, supply-all-three-nutrients-in-DAP-13\%S-or-DAP-15\%S mixtures; or all four in a combination N P K S fertiliser (e.g. Cropmaster 15). The mixtures with $50 \% \mathrm{~S}$ superphosphate have the advantage of restricting $\mathbf{S}$ losses by leaching compared with sulphate forms.

\section{$S$ fertilisers for dryland plains}

The dryland pastures on the plains are mainly on dry subhygrous yellow-grey earth soils over-lying gravel. Pasture type is more important on these soils than on others in the area. With shallow rooted grass-clover pastures maintenance $\mathbf{S}$ should be applied in a slowrelease form (e.g. $\mathbf{S}$ superphosphates) to restrict losses by leaching beyond the narrow rooting zone and fertiliser should be applied every 1-2 years.

Lucerne pasture is capable of taking up sulphate from the soil profile to a depth of $>100 \mathrm{~cm}$ in these soils. From studies conducted at Omarama in North Otago on similarly shallow soils overlying gravel, and under a similar rainfall of about $600 \mathrm{~mm}$ per year, leaching through this depth is likely to take 2-3 years (Boswell \& Swanney 1988). Under these circumstances superphosphate is likely to be as effective as slowrelease $S$ fertilisers.

\section{Soils on limestone}

Two situations are likely: drier soils which are high in $\mathrm{P}$ and $\mathrm{K}$ require only $\mathrm{S}$; and soils under higher rainfall (1000-1200 mm) which have low available P and S require both nutrients. For pasture maintenance a high analysis slow-release $S$ fertiliser e.g. 50\%S superphosphate is required for the soils with high $\mathrm{P}$ content; while for the soils with P deficiency $20 \% \mathrm{~S}$ or $28 \% \mathrm{~S}$ superphosphates are most suitable. Superphosphate should be applied at pasture establishment.

\section{S fertilisers for rolling hills}

Pastures on rolling hills are generally intensively grazed, fertiliser maintenance is probably applied annually or at least biennially. Slow-release $\mathrm{S}$ fertilisers are suitable for maintenance as is superphosphate, the choice depends on the ratio of other nutrients required. At a $S: P$ of 1:1 superphosphate or, when $\mathrm{N}$ is required, DAP $15 \% \mathrm{~S}$ are the best alternatives.

\section{Extensively grazed high country pastures}

Most of the high country is under a high rainfall $(>1600$ $\mathrm{mm}$ ) and is deficient in $\mathbf{S}$ and $\mathrm{P}$. For pasture maintenance a high analysis slow release fertiliser containing both $\mathrm{S}$ and $\mathrm{P}$ is required. $20 \% \mathrm{~S}$ or $28 \% \mathrm{~S}$ superphosphates are most suitable. The RPR $12 \% \mathrm{~S}$ -would-also-be-effective-in these pastures especially at recommended application frequencies of 2-3 years. In situations of severe financial constraint the use of a high analysis $S$ fertiliser (e.g. 50\% $\mathrm{S}$ superphosphate) to meet pasture $S$ needs but only partially meet $\mathrm{P}$ needs, may be a practical short term remedy to correct the more rapid losses of $\mathbf{S}$ from the system. This is not recommended as a continuing long-term policy. At pasture oversowing use superphosphate or $20 \% \mathrm{~S}$ superphosphate at about $50 \mathrm{~kg} \mathrm{~S} / \mathrm{ha}$; this will be sufficient for 2 years (McIntosh et al. 1985).

\section{REFERENCES}

Boswell, C.C.; Friesen, D.K. 1993. Elemental sulfur fertilizers and their use on crops and pastures. Fertilizer research 35: 127-149.

Boswell, C.C.; Thorrold, B.S.; Watkinson, J.H.; Lee, A.; Power, I.L. 1992. Effect of soil

temperature on the rate of oxidation of elemental sulphur. Proceedings of the New Zealand Grassland Association 54: 49-53.

Boswell, CC.; Swanney, B. 1986. Alternative sulphur fertilisers in New Zealand. Proceedings of the New Zealand Grassland Association 47: 233-242. 
Boswell, C.C.; Owers, W.R.; Swanney; B.; Rothbaum, H.P. 1988. Sulfur/sodium bentonite mixtures as sulfur fertilizers.1. The effects of S/Na-bentonite ratios on the rate of dispersion and particle size distribution of elemental sulfur dispersed from laboratory-produced prills. Fertilizer research 1.5: 13-31.

Close, M.E.; Woods, P.H. 1986. Leaching losses from irrigated pasture: Waiau Irrigation Scheme, North Canterbury. New Zealand journal of agricultural research 29: 339-349.

During, C. 1984. Fertilisers and soils in New Zealand agriculture. 3rd Edition. Government Printing Office Wellington, NZ.

Lee, A.; Watkinson, J.H.; Orbell, G.; Bagyaraj, J.; Lauren, D.R. 1987. Factors influencing dissolution of phosphate rock and oxidation of elemental sulphur in some New Zealand soils. New Zealand journal of agricultural research 30: 373-385.

McIntosh, P.D.; Sinclair, A.G.; Enright, P.D. 1985. Responses of legumes to phosphorus and sulphur on 2 toposequences of North Otago soils, New Zealand. New Zealand journal of agricultural research 28: 505-515.

Nguyen, M.L.; Goh, K.M. 1992. Nutrient cycling and losses based on mass-balance model in grazed pastures receiving long-term superphosphate applications in New Zealand. 2.Sulphur. Journal of Agriculural Science Cambridge 119: 107-122.

Nguyen, M.L.; Goh, K.M. 1993. Factors affecting plant sulphur requirements in New Zealand pastoral soils and arable systems. Proceedings of the $\mathbf{X V I I}$ International Grassland Congress 1993. 2: 14331436.
Nguyen, M.L.; Rickard, D.S.; Quinn; B.F. 1983. Sulphur requirements under irrigated pasture. pp 150-163 In: Gregg, P.E.H.; Syers, J.K. eds Proceedings of the technical workshop on Sulphur in New Zealand Agriculture. Massey University, Palmerston North Saggar, S.; Mackay, AD.; Hedley, M.J.; Lambert, M.G.; Clark, D.A. 1990. A nutrient transfer model to explain the fate of phosphorus and sulphur in grazed hill country pasture. Agriculture, Ecosystems and the environment 30: 295-315.

Sinclair, A.G.; Boswell, C.C.; Comforth, I.S.; Lee, A.; Morgan, C.; Morton, J.; Nguyen, L.; Saunders, W.H.M.; Shannon, P.; Smith, R.G.; Whelan, G. 1985. Agronomic requirements for sulphur in New Zealand pastures. Proceedings 20th Technical Conference NZ Fertiliser Manufacturers' Association 2: 538-572.

Syers, J.K.; Adams, J.A.; Walker, T:W. 1970. Accumulation of organic matter in a chronosequence of soils developed from wind-blown sand in New Zealand. Journal of soil science 21: 146-153.

Walker, T.W.; Gregg, P.E.H. 1975. The occurrence of sulphur deficiency in New Zealand pp 145-153 In: McLachlan, K.D. ed. Sulphur in Australsian agriculture. Sydney University Press

Watkinson, J.H.; Lee, A. 1994. Elemental sulfur: the rate of release in pastoral soils under New Zealand climate. Fertilizer research 37: 59-68.

Williams, P.H.; Haynes, R.J. 1992. Balance sheet of phosphorus, sulphur and potassium in a long-term grazed pasture supplied with superphosphate.

Fertilizer research 31: 51-60. 